\title{
In 111 Monoclonal Antibody LL2
}

National Cancer Institute

\section{Source}

National Cancer Institute. In 111 Monoclonal Antibody LL2. NCI Thesaurus. Code C2217.

A radioimmunoconjug ate of the humanized IgG1 monoclonal antibody (MoAb) LL2 (epratuzumab) labeled with indium 111 (In-111). MoAb LL2 recognizes CD22, a Blymphocyte-restricted antigen expressed as a cytoplasmic protein in progenitor B cells, and as a cell surface protein in mature B cells. In-111 MoAb LL2 emits gamma radiation and X-Ray photons that can be captured by gamma camera allowing imaging of tumor cells that express CD22 antigen. 